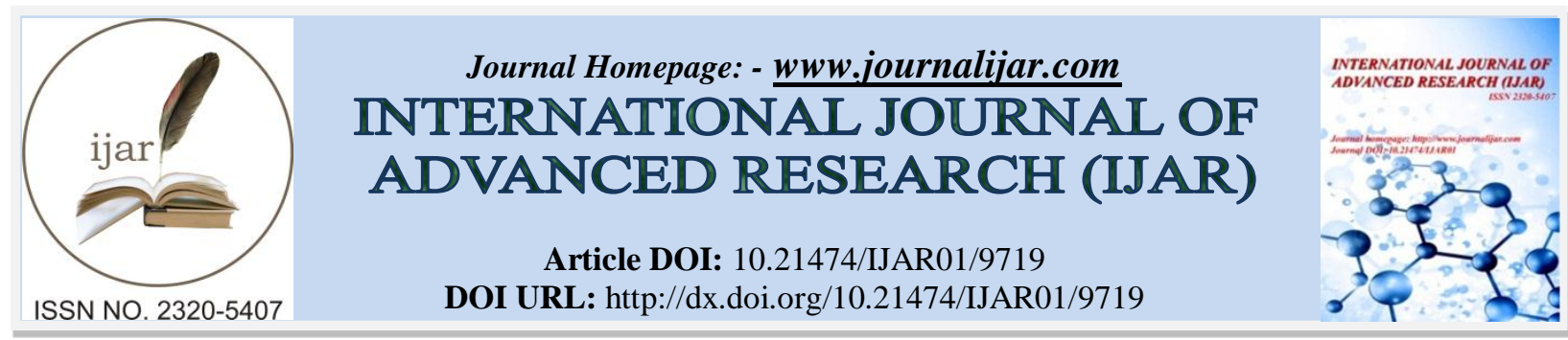

RESEARCH ARTICLE

\title{
ABUSE AND EXPLOITATION OF DOMESTIC WOMEN WORKERS IN INDIA- A HUMAN RIGHTS PERSPECTIVE.
}

Prof.V Sudesh and Mrs.DhanalakshmiC.V.

\section{Manuscript Info}

Abstract

Manuscript History

Received: 09 July 2019

Final Accepted: 12 August 2019

Published: September 2019

\section{Introduction:-}

"There is a looming human rights crisis close to our homes. The Situation of domestic workers in India is a failure of all kinds of rights".

Rishi Kant. ${ }^{1}$

Today we live in the technology era were in women are deprived of their dignity by being the victim of various crimes in every corner of the society. In the Indian economy, women workers play a significant role in contributing to the Gross Domestic Product (GDP). With the growing fragmentation of the labour force in India, employment without security has become the norm. ${ }^{2}$ Today women as a workforce actively participate both in formal and informal sectors. Unorganised sector workers constitute the most neglected class of Indian workers. Among the Unorganized sector workers in the full- time, women domestic worker is the oldest and part-time occupation for women in India. ${ }^{3}$ Domestic work is one of the oldest, age-old and most important occupations for millions of women around the globe. ${ }^{4}$ It is rooted in the global history of slavery, colonialism and other forms of servitude. ${ }^{5}$ The unorganised domestic work sector has a high absorption of labour employment, as the unpaid tasks of women in the household core tend to be more and more delegated to female domestic workers. The professional desire and aptitude of women in middle-class households in search of employment opportunities and career development outside their homes is the reason for the massive expansion in domestic work in India. Domestic work has increasingly become a significant part of the global division of labour force and inextricably integrated into the

${ }^{1}$ This article is the outcome of the Ph.D research on the topic "Rights of Women Workers in Informal Sector:A Study With Reference to Domestic Workers in India", under the guidance and Suprevision of Prof (Dr) Sudesh V, Dean, and Principal, PG Dept of Research and Studies in Law, ULC, Bangaluru.

${ }^{1}$ Research Scholar, University Law College, Bangalore University, Bangaluru and Asst. Prof of Law, Govt. Law College, Kolar.

${ }^{1}$ Director of Shakthi Vahini, an NGO protecting and defending human rights. \& Dr Sunil Yadav, Unorganized workers in India with special reference to the Unorganized worker's Social Security Act, 2008: Some Reflections, Labour law journal, 2010, Pg- 165-170.

${ }^{2}$ www.ilo.org.

3 Indispensable yet unprotected, working conditions of Indian domestic workers at home and aboard, by ILO, FUNDAMENTALS, 2015.

${ }^{4}$ Ncw.nic.in/Pdf files/Domestic worker welfare and social security Act 2010. Pdf, retrieved on Dec $16^{\text {th }} 2016$.

${ }^{5}$ A.Favire- Chamoux (Ed): Domestic service and formation of European identity: understanding the globalization of domestic work, $16^{\text {th }}-21^{\text {st }}$ cen (Bern, Peter Lang, 2004). 
unorganised labour force. While migration is an opportunity for the economic independence of the rural masses and the low-income families, but in the absence of assured social protection, it renders such workers more vulnerable to abuses and violations of human rights.

\section{Profile Of Domestic Workers-}

Employed domestic workers ease the burden of individual households by undertaking household chores in return for remuneration. There are more than a total of 40 million domestic workers in India, and nearly more than $90 \%$ of them are women. ${ }^{6}$ Domestic work is being commonly visualised as an activity with poor economic value and low social status, primarily performed by females, which replaces the traditional gendered roles performed by women at their household, as it is unpaid and undervalued. The variety of tasks performed by them include the care of children and elderly, cooking, driving, cleaning, grocery shopping, taking care of pets, particularly in urban areas.

In the absence of a formal contract of employment, domestic work forms part of the informal economy, which includes "all economic activities that are in law or practice not covered or insufficiently covered by any formal arrangements." "Domestic work is an avenue of employment, to poor rural women masses, who have limited access to education, and are left with no other choice of skilled employment. For many women worker, domestic work is a unique opportunity to earn in a socially acceptable manner and gain control over economic resources.

Presently, domestic workers make up a large portion of the workforce, especially in developing countries, and their number has been increasing even in the industrialised world. ${ }^{8}$ Unlike other forms of labour activity, domestic work takes place in a unique place of work that is not either a factory nor an office, but in the home. They do not perform the work alongside with other co-workers but in isolation behind closed doors. Prejudice and bias towards the domestic workers are based on their class, caste, the ethnic or racial origin that is often reflected very strongly at the workplace for many domestic workers. The National Survey on Domestic workers surveyed that they are in a state of dependency, exploitation and quasi-bondage. The Recent International Labour Organization (ILO) ${ }^{9}$ estimates based on National survey and census of 117 countries, place the number of domestic workers at around 53 million. The ILO estimates that $83 \%$ of domestic workers are women, and many are migrant workers, and globally at least 10 million children work as domestic workers. ${ }^{10}$ India has also witnessed a $75 \%$ increase in women's domestic workforce, accompanied by a significant increase in migrant domestic workers ${ }^{11}$ who are particularly vulnerable. Another striking change in domestic work has been the growing prevalence of child domestics. ${ }^{12} \mathrm{~A}$ substantial proportion of live-in domestics in developing countries are minors. More girl children under 16 are in domestic service than in category of child labour. ${ }^{13}$ The growing significance and demand for domestic work in paid employment in India make it all the more imperative to ensure that such work is being recognised with dignity and decent work with adequate pay.

\section{Definition Of Domestic Workers}

In India, there is no clear and accurate definition of the term domestic workers. The National Policy on Domestic Workers, as recommended by the Taskforce on Domestic workers, ${ }^{14}$ defines domestic work as:

"a person who is being employed, for remuneration whether in cash or kind, in any household, through an agency or directly either on a temporary or permanent basis, part-time or full time to do the household work or allied work, but does not include any member of the family of an employer."

\footnotetext{
6 As per survey done by National platform for domestic workers in the year 2010.

${ }^{7}$ ILO, Resolutions and Conclusions concerning decent work and informal economy, Indian Labour Congress, $90^{\text {th }}$ session, 2002.

${ }^{8}$ D.E Roberts:" Spiritual and Menial housework," Yale Journal of Law and Feminism, Vol 9, No 57, 1997.

${ }^{9}$ Report of ILO- 'Domestic workers across the world - global and regional statistics and the extent of legal protection/ILO-Geneva-2013.

${ }^{10} \wedge$ jump ${ }^{\wedge} \mathrm{to} ; \mathrm{ab}[1]($ dead in $\mathrm{k})$.

${ }^{11}$ Helma Lutz's report on 'Migration and Domestic work.'

12 www.ilo.org/ipec/areas/child domestics labour/lang-en/index-htm-ILo on domestic labour, global figures, accessed on 2017 Jan $12^{\text {th }}$.

${ }^{13}$ ILO, Helping Hands or Shackled lives? Understanding child domestic labour and responses to it, ILO-IPEC, Geneva, 2004.

${ }^{14}$ National Centre for Labour.org/about us.html.
} 
The ILO Convention No 189 defines "domestic work" as "work performed in or for a household or households."15 And the term 'Domestic worker' is defined as "any person engaged in domestic work activities within an employment relationship."16

The numerous factors such as sheer economic necessity, poverty, family problems, rural and male unemployment, alcoholic husband, urbanisation and attraction towards the glamorous city, indebtedness, illiteracy, and migration have necessitated women to take up jobs as domestic servants. The workers range from full-time to part-time workers, skilled and unskilled workers. The prevalence of clandestine and unregulated work relationships in this occupation makes it quite impossible to give even a rough estimate of the number of domestic workers worldwide or the economic value of the service they provide. ${ }^{17}$

\section{Abuse And Exploitation Towards Domestic Workers}

In the $21^{\text {st }}$ century, movements for labour rights, women rights and migrant workers rights, the conditions witnessed by domestic workers at the place of work and the problems specific to their class of employment have come to the fore. ${ }^{18}$ As women currently dominate the domestic labour market throughout the world, they have learned to navigate the system of domestic work both in their own countries and abroad. Various abuse and exploitation, witnessed by the domestic workers, have become the rule of the day for most of the domestic women workers across the globe. The abuses are excessively long working hours without rest, no decent wages, unfavourable working conditions, no defined work time, unpaid wages for month or years, forced confinement in the workplace (especially live-in workers), no weekly offs, loneliness, violence, verbal, physical, psychological and sexual abuses, and forced labour including debt bondage and trafficking by placement agencies. The exploitation faced by these workers is also rooted in gender discrimination and nationality among domestic workers. Wages paid are often below the statutory minimum, and there is no provision for overdue payment, health insurance and maternity benefit.

Female domestic workers, especially live-in workers who reside in their employer's home, are commonly vulnerable to sexual and physical abuse. Female domestic servants are being blended with Psychological abuses in the form of harsh insults; threats and belittlement combined with excessive demands for work are causes to put domestic workers, particularly young ones, to the brink of suicide. Physical aggression ranging from slaps, pulling or cutting of hair, severe beating or scalding with iron or hot water is the typical reaction of angry employers if the workers execute orders too slowly, forget tasks or breaks something. Live-in domestic workers are usually isolated, sometimes with extreme restrictions on their freedom of movement. However, in households with more than one employer, co-worker violence may also erupt because of rivalry between workers. Domestic workers are under the constant fear of termination from work. ${ }^{19}$

The various abuses faced by the domestic workers leads to multifaceted human rights violation that hinders their enjoyment of Right of life, liberty and freedom of movement. There are many occasional horror stories in the media about the poor treatment meted out to domestic women workers. ${ }^{20} \mathrm{~A}$ vicious circle is being created wherein the domestic workers involved are transferred to the status of victims in the world's third-largest organised crime. The conditions that they are exposed to at workplace very well fits into the bounded labour cases in an extreme situation. Compensation for injuries arising out of or in the course of employment is not accessible to a domestic worker. They have no access to medical expenses and insurance and benefit coverage as enjoyed by other formal workers. They

15 Article1 (a) "Domestic Work" as addressed in Convention No. 189 is distinct from "home-work" which, at the level of international labour standards is covered by Home Work Convention, 1996(No.177). Home work is work carried by workers in their own home rather than the workplace of an employer.

${ }^{16}$ Article 1(b) Domestic Workers Convention, 2011(No 189).

17 Asha D'souza, “ Moving towards Decent work for Domestic Worker: An Overview of the ILO's work” ILO, Working paper $2 / 2010$.

${ }^{18} \mathrm{http}$;//en.wikipedia.org/wiki/Domestic workers.

${ }^{19}$ Suneetha Eluri, Alok Singh, "Unionizing Domestic Workers: Case Study of INTUC- Karnataka Domestic Worker Congress, ILO, 2013, Pg 18.

${ }^{20}$ An Airhostess assaulted her 13 year old domestic help and locked her inside her house for which she was arrested and sent to 14 days judicial custody, reported in 'Deccan herald, New Delhi, Oct 31 ${ }^{\text {st }}$, 2013; Delhi court ordered a lawmaker and his wife(Dhananjay Singh and wife Jagriti Singh) to appear before the court again on Feb 22 for charges alleged over the death of their maid in November 2014. 
are not allowed to enjoy any old-age pension, gratuity, retirement benefits or bonus. ${ }^{21}$ The domestic women workers are not vouchsafed from any fair labour treatment and are being exempted from any form of legal protection against glaring violation of human rights abuses.

Due to the 'hidden' character of domestic work, abuse is less visible. ${ }^{22}$ Despite the vital role, the domestic workers are the most exploited and abused section of informal sector workers across the globe. Children and migrant domestic women workers are often the most vulnerable. ${ }^{23}$ Indeed, the exploitation and abuse that many domestic workers face stem from the hidden and informal arrangements, lack of employment contracts, cross border migrations and inability to file a complaint or seek redress in courts. ${ }^{24}$ The endless and repetitive services provided by these workers are not acknowledged and recognised as valuable and visible work. ${ }^{25}$

The actual data released by the Ministry of Women and Child Development for the year 2014, track reports on violence against domestic helpers between 2010 and 2012 state that West Bengal has the highest number of cases of such abuses in 2012, with 549 maids and helpers filing complaints against their employers. The Southern State of Tamil Nadu has registered the second-highest number with 528 cases, while it's neighbouring State Andrapradesh has the third-highest numbers with 506 cases recorded over the same period. ${ }^{26}$

The under-estimated, un-reported statistics and the gendered nature of work, make the domestic workers invisible. These workers lack organisational strength and voice and comprise of mostly unskilled women, who enter the labour market without any technical skills. Therefore, domestic workers warrant special attention rather than exclusion. ${ }^{27} \mathrm{~A}$ significant obstacle in providing a solution to the problems faced by domestic workers is the absence of a legal protection system. The stories of abuses told by domestic workers around the globe demonstrate the profound human cost of negligence and discrimination they experience at the respective workplace. ${ }^{28}$ Frequent exploitation by the placement agencies or intermediaries in various forms, such as demanding high commission or fees from both employer and employee ${ }^{29}$ and practising forced labour ${ }^{30}$ are on the rise.

\section{Domestic Workers And International Migration}

Migration $^{31}$ of domestic workers is a phenomenon that emerges out of the need for food and satisfaction of once own desires and necessities. Many countries import domestic workers from aboard, usually from developing countries, through recruitment agencies and intermediaries. The primary inflow of migrant domestic workers is from countries such as Thailand, Indonesia, India, the Philippines, Bangladesh, Pakistan, Srilanka and Ethiopia. ${ }^{32}$ The migration of domestic workers left with no protection can lead to several different effects both on the host countries and sending countries. The domestic workers face wide range of abuses including unpaid wages, confiscation of passports, physical and verbal abuses, confinement within the homes of employers, lack of proper accommodation and forced labour. The recent issue of ill-treatment given by an Indian diplomat to her maid in the US caused a diplomatic rift between the two countries in Dec 2013. ${ }^{33}$

${ }^{21}$ Despite almost a century of Servitude, 111 tear old Rosa Vazhapilly receives no pension or social protection.

22. Sindhu Menon, On Domestic workers day, Millions of Indian women continue to work in the shadow, Equal times.org, 16 june, 2015.

${ }^{23}$ Study, "Invisible Servitude: An in-depth study of domestic workers in the world; by Social Alert.

${ }^{24}$ Amitava Ghosh, "How long can we ignore the plight of domestic workers" Yale Global.

25 Jagori report. www.jagori.org.

${ }^{26}$ Source -National Crime Record Bureau, reviewed by Wall street journal. Overall, in India's 28 states and 7 union territories, there were 3,564 cases of alleged violence against domestic workers reported in 2012, up slightly from 3,517 in 2011 and 3,422 in 2010. (UN in India).

${ }^{27}$ wiego.org/informal economy law/domestic workers-India.

${ }^{28}$ Human Rights Watch, Swept under the rug: Abuses against domestic workers around the world, 2006, Pg. 2.

29 At New Delhi, a placement agency collect as much as 25000/- to provide domestic workers for a year. The contract comes to an end after 12 months and again employer has to shed commission for new employee.

${ }^{30}$ www.hrln.org/hrln/womens-justice. accessed on $2018 \mathrm{Dec}^{16} 6^{\text {th }}$ at $10 \mathrm{pm}$.

${ }^{31}$ The law governing and regulating Migration in India is Interstate Migrant Workmen(Regulation of Employment and Conditions of Service) Act 1979.

${ }^{32}$ Supra n 30

${ }^{33}$ American authorities indicted an Indian diplomat in New York for visa fraud after they said she had violated visa rules governing pay and conditions for domestic workers brought from aboard. 


\section{International Mandate And Protection Of Domestic Workers}

In 2011, the International Labour Organization adopted a convention concerning decent work for domestic Workers (No 189) to imbibe humanitarian value, to acknowledge workers as a worthy human being. The Convention typically outlines the fundamental postulate of rights for domestic workers and provides a guideline on terms and conditions of employment, wages, working hours, occupational safety and health, social security and the avoidance of child labour. India has yet not ratified the said convention, but she has signed the agreement. The chief goal of the International Labour Organisation, today is to promote equal opportunities for women and men to obtain decent and productive work environment in conditions of freedom, equity, security and human dignity. ${ }^{34}$ Indeed, domestic work is one of the occupations where a deficit of decent work is highest, and situations of quasi- slavery are being still found. As of now, 22 nations have signed the convention, but the US and India have yet not ratified the said convention.

The Constitution of India guarantees the fundamental right to equality to all citizen and the fundamental principles of rights to livelihood and rights at work apply to all women and men who engage in economic activity including domestic work. The domestic workers like other workers are entitled to the rights such as the right to work, the provision of just and humane conditions of employment, maternity leave and right to a living wage. However, the domestic workers remain more like bounded labour without enjoying the rights guaranteed to them.

\section{Conclusion And Suggestion:-}

Domestic workers are the engines that set the life of many women at household to seek jobs outside their home to develop and prosper in their career development. Domestic work in the present global economy, therefore, poses a significant challenge for the national regulators and economist. The domestic workers are an essential category that tends to be de-jure or de- facto unprotected. The prime reasons for their plight are lack of proper labour laws that govern them, indifferent attitude and want of an appropriate forum that can take up their causes. Ensuring fundamental rights perceptibility for the domestic workers is to be based on their social and political mobilisation, which can affect the current labour market conditions. However, it also requires a significant change in the attitudes and behaviour of their employers, who constitute not just the wealthy elite groups in the country but also a growing number of middle-class beneficiaries of the economic growth process. Focusing on and addressing the multifaceted abuses and the protection strategies for domestic workers in the Indian context is an arduous task. As these workers are not included within the definition of the term 'industry' ${ }^{35}$ because household and home are being presumed as a 'non-industry' entity, that is outside the purview of existing labour laws.

Recognising the vital role that domestic workers play and their vulnerability to exploitation stresses the need for enacting National legislation, which recognises domestic work alone as real work, and not merely as an extension of unpaid household and care work is an urgent need of the hour. It is high time for India to meet with the labour standards of ILO for securing social justice for domestic workers in India through ratifying the Conventions No 189 and No 201 and guaranteeing decent work conditions and upholding their rights. There is also an inevitable necessity for the inclusion of domestic workers in the mainstream of labour laws. The work of domestic workers is devalued and considered unproductive.

The latest in a series of efforts to address the concerns of Domestic Workers are the two draft bills brought out in 2008 by the National Commission for Women and the National Campaign Committee of Unorganized Sector Workers also in 2008. Organising domestic workers has been a massive challenge as the workplace is inaccessible and multiple, marked by a high rate of attrition and instability. Policymakers, legislative bodies and people need to recognise the existence of an employment relationship in domestic work. Such a view would see them as not just "helpers" who are "part of the family" but as employed workers entitled to the rights and dignity that employment brings with it.

${ }^{34}$ ILO, "Decent Work", Report of the Director General, ILC, $87^{\text {th }}$ session, 1999, Pg 3.

35 . Domestic workers though employed by the company working at residential houses of officers who control and supervise their work, held as not covered by definition of employee under U.P. Shops \& Commercial Establishments Act,--Ganesh Flour Mills Co.Ltd., Kanpur Vs Labour Court, Allahabad,-1971(22) FLR_P.172(Allahabad High Court). 
The legislation such as Unorganized Workers Social Security Act, 2008, Sexual Harassment against women at workplace (Prevention, Prohibition and Redressal) Act, 2013 and Minimum wages schedules, ${ }^{36}$ have been notified in various States referring to domestic workers. But there remains a total absence of a comprehensive, uniformly applicable national legislation that guarantees fair terms of employment and decent working conditions for domestic workers. In the final analysis, India should enact legislation, which reflects its constitutional principles and guarantees of state policy as per the international labour norms. We should not tolerate a situation, where the legitimate concerns for domestic workers especially women and girl children who are dominantly participating in this kind of employment, have been overlooked to the benefits of the employers, especially those who are unwilling to pay a living wage, or treat servants with dignity and respect, which is their respective due. We should pay empathy towards rather than sympathising because they are the need for the urban homes without whom the life cycle of all of us will be shattered.

The significant challenge here is to move beyond the formal but mostly invisible- inclusion of domestic workers into the existing labour legislation through amendments and towards recognition of the specific regulation of their employment and their real visibility. Restoring dignity, to millions of domestic women workers generally and upholding their fundamental human rights, which has been violated day after day, therefore it is the duty of all the stakeholders, i.e., government, trade union, associations of employers and concerned civil society organisations, to strive for social justice.

To conclude in the words of Manu

"Yatra naryasthu poojyanthe, ramanthe thatra devethaha."

\footnotetext{
${ }^{36}$ Notification for Domestic Workers were passed in the following States-Kerala (23 ${ }^{\text {rd }}$ May2005); Andhra Pradesh (24thApril 2007) and Rajasthan( $4^{\text {th }}$ July 2007),
} 